\title{
Coquetting Females versus Males of Manners: Critical Discourse Analysis of Egyptian Street Songs
}

\author{
Mai Samir El-Falaky (Corresponding author) \\ College of Language and Communication, Arab Academy for Science and Technology \& Maritime Transport, Cairo, Egypt \\ E-mail: maismf@hotmail.com \\ Al-Shaymaa Mohamed Mohamed Ahmed \\ College of Language and Communication, Arab Academy for Science and Technology \& Maritime Transport, Cairo, Egypt \\ E-mail: shima19.7@gmail.com
}

Doi:10.7575/aiac.alls.v.6n.5p.190

URL: http://dx.doi.org/10.7575/aiac.alls.v.6n.5p.190
Received: 29/04/2015

Accepted: 04/08/2015

\begin{abstract}
The study explores gender differences and the role of the ideological background in portraying the roles of the males and the females. Socio-economic statuses affect the description of gender differences and this is proclaimed within the analysis of a recent phenomenon of poor quality street songs. The study represents a detailed description of male and female relationship, so as to spot the light on the literary and societal implications of this newly propagated genre. The study analyses two common songs spreading among commoners distorting the woman's image predefined in the Egyptian culture. Negative cultural and societal conceptions are explicitly mentioned about the relation between males and females.
\end{abstract}

Keywords: gender, media representation, discourse analysis

\section{Introduction}

Egyptian folklore is one of the artistic genres that displayed in different forms. By the turn of the 21st century, Egyptian folklore has been influenced by the emergence of television till the technological revolution that led to the spread of this type of songs throughout all the people. The deterioration in the artistic taste has been noticed especially when the socio-economic situations have encountered drastic changes.

In the Egyptian society, which is the main focus of this study, people have witnessed two revolutions, four presidents in less than four years. During that period, the Egyptian people are divided into a number of social groups, one of which is considered the main reason for the deterioration of the folklore and the making of that new kind of music type called Mahraganat.

This genre has been defined to be one of the worst types of music but at the same time, the most spread among youth especially the male ones. These songs are characterized by having a plot, a protagonist and villain. Generally, the plot is woven in a sexual context, the protagonist is the male striving character and the villain is the female character who is trying to destroy to the hero's life.

\section{Review of Literature}

Discourse Analysis emerges as a result of the lack of examination of nationalist ideologies, social movements and the political construction of social identities (Howarth and Stavrakakis, 2000). The emergence of Discourse Analysis (DA) is, also, prompted by the need to study both the making and unmaking of political institutions and topics of political science, such as voting behaviour and political decision making. Howarth and Stavrakakis (2000) claim that "issues of identity formation, the production of novel ideologies, the logics of social movements and the structuring of societies by a plurality of social imaginaries are central objects of investigation for discourse theory" (p.1-2).

van Dijk (1997a) manifests the importance of DA as being studied "not only as a form, meaning and mental process, but also as complex structures of interaction and social practice and their functions in context, society and culture" (p.7). This kind of interaction, as proposed by van Dijk, is intentional, controlled and purposeful that aim at communicating acts.

Liu (2008) adds that this form of social practice is tied to specific historical and socio-cultural contexts. He also asserts that discourse is regarded as a means by which existing social relations and identities are produced or contested and challenged. Besides, Fairclough manifests the dual character of Discourse Analysis claiming that

Discourse analysis correspondingly has a doubly relational character: it analyses relations between discourse and other elements of the social, and it analyses relations 
between linguistic/semiotic elements of social events and linguistic/semiotic facets of social structures and social practices, including 'discourses' (2005, p.916).

Based on van Dijk's approach to discourse analysis, Butler (2003) views some of the principles that discourse study should adopt. He claims that the study of discourse must deal with authentic, naturally occurring data. It must also recognize the dynamic nature of discourse. Participants, as Butler argues, act as members of particular social and cultural groupings and not only elements of the discourse. More importantly, the study of discourse must describe the functional and semantic relationships between its units.

Ultimately, researchers agree to use discourse analysis as a methodological tool, as it is an essential part of the social practices. They reach a conclusion that every text is influencing and at the same time influenced by its social context.

\subsection{Ideology and the Construction of Reality}

Generally, 'ideology' refers to all the meaningful constructions such as belief structures, constructions of reality or discursive practices. Much research (Fowler and Kress, 1979; Poynton, 1989; Stavrakakis, 2000) is based on describing ideology as 'world view'. This world view comes to language-users from their relation to the institutions and the socioeconomic structure of the society. In this respect, "the ideological constructions of reality attempt to provide a final symbolization of the world around us...." (Stavrakakis, 2000, p.101). Supportingly, Poynton (1989) states that the ideological constructions represented in the language play a vital role in the construction of reality in three interrelated ways:

(1) by naming aspects of the physical and social reality speakers inhabit that are seen as significant in a particular culture; (2) through the ways of speaking that are characteristic of a particular culture, not only insofar as named aspects of the culture are embedded within them, but particularly insofar as they make possible the enactment of social institutions and social values; (3) through covert grammatical categories ... particularly when these form congruent sets [which are called] grammatical 'conspiracies.' (p.12)

Another aspect of ideology can be found in Thompson's study of the ideological theories. Thompson (1984) describes three 'modes' in which ideology operates, namely, 'legitimation', 'dissimulation' and 'reification'. Legitimation, for Thompson, means that domination seeks to gain its legitimacy "appealing either to rational, traditional or charismatic grounds and such an appeal...is generally expressed in language." (p.131). Second, 'dissimulation' where relations of domination tend to be concealed presenting themselves as something other than what they are. A third way in which ideology operates is by means of 'reification' which means "representing a transitory, historical state of affairs as if it were permanent, natural, outside of time." (Thompson, 1984, p.131).

\subsection{Naturalization of Ideologies}

Fairclough (1995) describes the term 'Naturalization' as a result of giving a particular ideological representation the status of 'common sense', "and thereby makes them opaque, i.e. no longer visible as ideologies"(p.42). These ideologies would, then, seem as norms typical of the institution and typical of members of this institution.

Ideologies are said to be powerful and effective when its workings are least visible. Fairclough (1989) says,

If one becomes aware that a particular aspect of common sense is sustaining power inequalities at one's own expense, it ceases to be common sense, and may cease to have the capacity to sustain power inequalities, i.e. to function ideologically. (p.85)

Naturalization of ideology, thus, depends on the power exercised by a certain institution or social group. It is the ideology of the powerful groups that dominates to the extent that it becomes a common sense affecting the discourse produced and interpreted within the other groups.

Pennycook (2001) describes the goal of CDA: is that it makes the social ideological systems and representations transparent and to show how they are related to the broader social order (p. 81). Still, Pennycook (2001) links power to ideology. They state that both are interrelated and can be represented in a complex chain of relations.

Ideological positions can be uncovered in texts; ideologies are the concealed views of particular social groups; those groups that frequently manage to promote their ideological position to the extent that it becomes naturalized are able to do so because of their social power, reproducing their ideologies, they are therefore able to reproduce social relations of power (Pennycook, 2001, p.81).

\subsection{Who Is Powerful and Who Is Superior}

'Power' is defined as a form of social activity exercised by a certain person to get someone to do something. Watt (1991) exemplifies this definition as follows:

$\boldsymbol{A}$ exercises power over $\boldsymbol{B}$ when $\boldsymbol{A}$ affects $\boldsymbol{B}$ in a manner contrary to $\boldsymbol{B}$ 's initially perceived interests, regardless of whether $\boldsymbol{B}$ later comes to accept the desirability of $\boldsymbol{A}$ 's actions. (p. 62) 
It is largely agreed upon that language gains its power through its deployment within the agendas of powerful people. And the notion 'powerful' here is associated with rank and status, as hierarchies are built around the relative positions of social, professional and political power (Wang, 2006). For Wang, "...power can be characterized as the ability to control and constrain others; as the capacity to achieve one's aim; as the freedom to achieve one's goals and as the competence to impose one's will on others" (p.531).

Mayr (2008) names three strands of research that have been identified in the study of the relationship between discourse in a certain institution and power:

(1) the study of how members of oppressed groups can 'discursively penetrate the institutionalized form of their oppression'; (2) how subordinate individuals 'discursively frame their own subordination' thereby perpetuating it; and (3) analysis of how dominant groups 'discursively construct and reproduce their own positions of dominance'. (p. 3)

Wodak and Clarke (2009) argue that this power is exercised through three related modes, i) the power in discourse; ii) power over discourse; and iii) the power of discourses. They claim that the first mode refers to the struggle of different actors over different interpretations of meaning through practices related to the selection of specific linguistic codes and rules for access to meaning-making forums (i.e. meetings) and interaction (i.e. turn-taking, decision-making, etc.). The second mode, according to them, refers to means through which various groups of actors are denied or granted 'access to the stage' through processes of inclusion and exclusion. The third and final mode is interconnected with ideological production and their interpretations (Wodak and Clarke, 2009, p.278).

One of the crucial tasks of discourse analysts is to study the relationships between discourse and all the modes of social power. van Dijk (1997a) defines social power as a concept that organizes relationships between discourse and society. According to van Dijk (1997a), the discursive exercise of power has various forms which are interrelated together as a closed circle. First, social power can be represented in the control of action and mind. This kind of control does not take place through the form of coercive power, by police or military men. Rather, it is a mental process that controlling others by giving commands or orders and similar direct speech acts.

Another form of power is the 'persuasive power'. This includes controlling the minds of others so that they will act as we want. "Instead of ordering others, we may persuade them to do something."(van Dijk, 1997, p.18). van Dijk points to the fact that there are some discourses that succeed in controlling the minds of others to the extent that they convince them to do what is needed out of their free will.

Another fundamental relationship between power and discourse is called 'access'. This form of power does not only control material resources, but it also includes the control of the elite of many types of public discourse, for instance in politics and media and so on. van Dijk specifies the strategies of access as:

...who controls the preparation, the participants, the goals, the language, the genre, the speech acts, the topics, the schemata, the style, and the rhetoric, among other text features, of communicative events. That is, who can/may/must say what, to whom, how, in what circumstances and with what effects on the participants? (1996, p. 102)

This, thus, concludes that social groups (or members of these groups) do not have equal access. Instead, all social practices suggest that there is a dominant group which has more access than the dominated group which has less access and, thus, are supposed to be less powerful.

\subsection{Social Practice and its Structure}

van Leeuwen (2008) assumes that all actually performed social practices are characterized by having some elements. First and foremost, 'Participants', represented as agents or beneficiary is a key element in social practices. A debate for example, needs candidates, voters, or interviewers. Participants should be eligible, i.e. they should have the appropriate qualifications that fit their role in society. Participants should, also, have the appropriate presentation styles including 'dress and grooming', which guarantee that their practice is fulfilled the way they should be.

'Actions' are the core of any social practice. They are performed in a certain sequence and performed in a certain mode. 'Performance Mode' of the social practice refers to the pace according to which actions take place. 'Times' and 'Locations' are also, crucial elements that characterize the social practice. That is, any social practice should take place in a specific time and location. Last but not least, 'Resources' are introduced by van Leeuwen to refer to the tools or the 'props' that are needed to perform the social practice, such as a microphone or video cameras in a debate (van Leeuwen, 2008, p.12).

Fairclough and Wodak (1997) describe CDA as analyzing real social interactions which take a linguistic form. It views the deep relationship between language and society. In other words, "It is a form of intervention in social practice and social relationships". (Fairclough and Wodak, 1997, p. 258). This, in turn, as van Dijk (1997a) claims, attract the attention to its interdisciplinary nature, as combining diverse perspectives in its own analysis, hence enabling to address a vast number of social problems. 
The study seeks to uncover the structure of street songs and how this structure succeed to reflect social structure with all it constituents. The study aims at analyzing the settings in which the songs are produced and spotting the light on the societal implication of the spread of such artistic phenomena

\section{Analysis}

\subsection{O Men, Beware of the Feminine Sexuality}

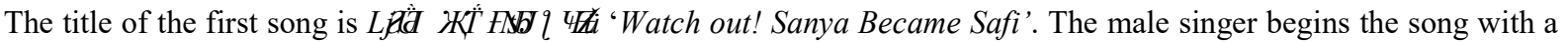
distress call to all the other males. He is warning his gender that the girl has changed her name from an old-fashioned name to a more modern-like one. The singer, then, proceeds with a description of her sexual attitudes with the males within her residential slum. He is warning her of the harmful things that could happen to her due to her inappropriate behaviors. He is calling her $\square$ which is a vocative of a low-standard girl. This belittling look is followed by an accusation that she creating a virtual life attempting to deceive the surrounding males.

The following description is also a derogatory representation of any Egyptian female. According to the singer, Sanya 'is friending a low-standard boyfriend'. This description represents an accusation in the context of the Egyptian culture; such attitude diverges completely from the norms and ethics known in conservative societies. It represents an accusation of adultery. The portrayal of the female extends to reach the mother who does not oppose her behaviour. On the contrary, she supports her by calling the daughter by a nickname and by giving her money 'ok Kuuky, take this money'. Interestingly, the voice of narration in that first part of the song is a third person voice. The singer is trying to draw an image of his rejection by distancing himself from her completely.

In the second half of the song, the narrator shifts the voice of narration to the first person method of narration. This shift may be ascribed to the desire to attack her and accuse her face-to-face with her inappropriate behaviors. Such description takes place with in the frame of criticizing her sexual attitudes. "Another form of deprecation can be seen in the fact that there are many more sexual and sexualizing term relating women than there are to men." (Basow, 2001, p.128)

The singer commences this part by picturing her physical appearance. The male broadened the portrayal showing his dissatisfaction by such fake outward show which differs from actual upraising traditions. Her hair is frizzy عامله شعرك كان مانشية من وسط الحته and 'walking in the middle of the slum'. كمان هتقلبلي لسانها 'also she is code-switching'. These two images are considered odd especially in a social group known of its female conservation and is always seen as veiled strict women. The singer ends the picture with a direct accusation of her cheating and her sexuality, i.e. she is friending five or six boyfriends at the same time 5 , و مصاحبة يجي . The patriarchal hero here is condemning her attitudes and trying to warn her يا سنيه عيب بقى لميها و متسوقيش فيها كيه 'Sanya, watch out! Do not over-act.' His warning is mixed with a gentle blame to her femininity which should be taken care of by her own self. According to the female singer, she is the beauty that should be sung for. Thus, if she does not get back to her original life she will face so hard times يا سنية على نفسك خافي 'O Sanya! Watch out for yourself.'

It goes without saying that language plays an important role in stereotyping women. According to Basow (2001) "Linguistic stereotyping also focuses on males as the norm by emphasizing different qualities when females are described. Women are stereotyped both as sexual objects and as homemakers. As sexual objects, their appearance is commented upon in all arenas" (pp.127-8). This song, for example, focuses typically on the content of the masculine view of the females in his community. The above description of the song depicts the masculinity of the singer and the hero whose identity is represented as a man holding on strongly to his manhood and fighting, with all his power, the unaccepted norms produced by modern-like females.

This song, among others, seeks to stereotype the males in the role of heroes who strive against the females' immorality. The villain role that the female plays, in the song, is strongly interwoven by the employment of the language used and the voice of narration in the song.

\subsection{Who Wins: Flirting Women or Strong Men}

The second song دلع البنات which is translated as 'The Coquetting Girls'. The song represents a detailed description of girls who are pretending to be someone's they are not. Descending from low standard families, they show off as playful girls for the sake of attracting the males who, in turn, attempt to resist these seductive calls.

The song begins by describing the girl who intends to ride a car specifically for the targeted boy who is the singer of this song. The whole song proceeds in a first person narration voice. The first person pronouns used show that the male knows that he is the one targeted by her playful deeds. ركبالى العربية دلع بنات...عملالي اجنبيه "riding a car for me, appearing as a foreigner, for me". This rightful appearance happens in a poor slum called 'El Ameerya'. The narrator is calling for the help of the police to arrest and imprison these girls which are portrayed as a danger for his moral ideologies. The male is also calling for the public to watch and witness the calls of this coquette. The rest of the song represents a description of this girl who is dancing with the music with revealing songs saying here and there

$$
\text { لابسالى شيكا بيكا دلع بنات المزيكا دلع بنات }
$$

According to the singer, this made him crazy in an uncontrollable state of mind. And this is ascribed to the revealing شعر ها احمر ف اصفر دلع بنات 
وشها ازرق ف اخضر دلع بنات

لابسالى فستان اقصر دلع بنات

The male is calling for the stop of these immoral practices saying that he is powerless and helpless which means that if he does anything wrong this is because of the human instinct which can never resist such seductive actions of the coquetting girls.

\section{Conclusion}

This kind of songs has the purpose of the naturalization of a given ideology. That is, males are victims of the female sexuality. The language used in the lyrics of these songs justifies the propositions that put the woman in the frame of sexuality and the male in the role of the helpless hero. The representation of the male and females comes to be of the males' interest. The distortion of the woman's image is also supported by giving hints about the socio-economic background from which the women descend. Although the males may appear powerless before the woman sexuality, the language he uses is an absolute indication of his power. He has the power to judge what is correct and what is not. He has the authority to warn and advice her. From the previous analysis, the male is characterized by having the ability to change the reality just be his masculinity.

In this artistic genre of street songs, there is some kind of negotiations of social relationships and of social roles of the participants especially in the in the context of the Egyptian society. By analyzing the structures of the two songs, it is observed that interpersonal meanings are communicated between males and females. The analysis shows that when males attack the woman rivals, they are actually defending themselves from the accusation of oppressing the women. Males are attracting the audiences' attention and keep intimacy with them by exposing a common enemy, i.e. coquetting females. Throughout the analysis males are seen to avoid the authoritarian voice by mitigating their propositions, giving advice, orienting the audience to the females; flaws.

Creating a kind of dialogue, singer use different voices of narration. The analysis shows that when they aim at distancing themselves from the females' attitudes they use the third person method of narration. A shift to the first person narration takes place when the male seeks to portray himself as a man of ethics who advices her for her won sake. Such technique is used with the purpose of balancing social relations with other his gender of the opposing one. Thus it can be concluded that although women are virtually powerful, males are actually superior.

\section{References}

Allan, E. (2012). Policy Discourses, Gender, and Education: Constructing Women's Status. UK: Routledge Publications.

Basow, S. (2001). Androcentrism. In Encyclopedia of Women and Gender: Sex Similarities and Differences (Vol. 1, pp. 127-128).USA: Academic Press

Brown, G. \& Yule, G. (1988). Discourse Analysis. Cambridge: Cambridge University Press.

Butler, C. (2003). Structure and Function: A Guide to Three Major Structural- Functional Theories. USA: John Benjamin's Publishing.

Caldas-Coulthard, C. and Iedema, R. (2008). Identity Trouble:Critical Discourse and Contested Identities: UK: Macmillan.

Chouliaraki, L. and Fairclough, N. (2001). Discourse in Late Modernity. Edinburgh: Edinburgh University Press.

Dunmire, P. (2005). Preempting the Future: Rhetoric and Ideology of the Future in Political Discourse, Discourse Society, 16 (4), 481-513.

Duszak, A. (2009). Discourses “of course"? In Jan Renkema (Ed.). Discourse, of Course: An Overview of Research in Discourse Studies. (pp.37-51). USA: John Benjamins Publishing.

Eckert, P. and McConnell-Ginet, S. (2013). Language and Gender. USA: Cambridge University Press.

Fairclough, N. (1989). Language and Power. USA: Longman.

. (1995). Critical Discourse Analysis: The Critical Study of Language. USA: Longman.

(1996). Technologisation of Discourse. In Carmen Rosa and Malcolm Coulthard (Eds.), Texts and Practices. (pp. 71-83). London: Roultedge. (2003). Analysing Discourse: Textual Analysis for Social Research. London: Routledge.

(2005). Peripheral Vision: Discourse Analysis in Organization Studies: The Case for Critical Realism. Organization Studies, 26 (1), 915-939.

Fairclough , N., \& Wodak, R. (1997). Critical Discourse Analysis. In Teun van Dijk. (Ed.), Discourse Studies: A Multidisciplinary Introduction. Volume 2. (pp. 258-283). London: Sage Publication.

Fowler, R and Kress, G. (1979). Critical Linguistics. In R. Fowler, B.Hodge, et al (Eds.). Language and Control. (pp.185-213). London: Routledge and Kegan Paul.

Hawkes, D. (1996). Ideology. London: Roultedge. 
Hellinger, M. et.al. (2015). Gender across Languages: the Linguistic Representation of Women and Men. In Marlis Hellinger and Heiko Motschenbacher. (Eds.), Gender Across Languages. (pp. 1-26). USA: Johan Benjamin.

Howarth, D \& Stavrakakis, Y. (2000). Introducing Discourse Theory and Political Analysis. In David Howarth and Yannis Stavrakakis et al. (Eds.), Discourse Theory and Political Analysis: Identities, Hegemonies and Social Change. (pp. 1-23). USA: Manchester University Press.

Hyatt, D. (2005). Time for a Change: a Critical Discoursal Analysis of Synchronic Context with Diachronic Relevance. Discourse \& Society, 16 (4), 515-534.

Johnstone, B. (2008). Discourse Analysis. USA: Blackwell Publishing.

Kinsley, P. (2014, May 9). Cairo's Street Music Mahraganat both Divides and Unites. The Guardian. Retrieved from http://www.theguardian.com/world/2014/may/09/egypt-cairo-street-music-mahraganat-grime

Lakoff, R. (2004). Language and Woman's Place: Text and Commentaries. USA: Oxford University Press.

Liu, Y. (2008). The Construction of Patriotic discourse in Chinese Basal Readers. In Rosana Dolón and Júlia Todolí (Eds.), Analysing Identities in Discourse (57-82). USA: John Benjamins Publishing.

Martin, J. R. and Rose, D. (2005). Working with Discourse. London: Continuum Publishing Company.

Mayr, A. (2008). Introduction: Power, discourse and institutions. In Andrea Mayr (Ed.). Language and Power:An Introduction to Institutional Discourse. (pp. 1-25). London: Continuum.

Meyer, M. (2002) Between Theory, Method, and Politics: Positioning of the Approaches to CDA. In Ruth Wodak (Ed.) Methods of Critical Discourse Analysis. (pp. 14-30). London: Sage Publications.

Meyer, M \& Wodak, R. (2000). Methods of Text and Discourse Analysis. London: Sage Publications.

Mills, S. (2004). Discourse. London: Routledge.

Moore, J. D., \& Wiemer-Hastings, P. (2003). 12 Discourse in Computational Linguistics and Artificial Intelligence. In M. A., \& Goldman, S. R. (Eds.) Handbook of Discourse Processes, Graesser, A. C., Gernsbacher, (pp. 439-478). Mahwah, NJ: Lawrence Erlbaum Associates.

Nuyts, J. (1990). The Linguistic Representation and Conceptual Knowledge Representation. In Jan Nuyts et.al (Eds.) Layers and Levels of Representation in Language Theory: A Functional View. (pp. 295-312). USA: Johan Benjamin.

Renkema, J., (Ed). (2009). Discourse, of Course: An Overview of Research in Discourse Studies. USA: John Benjamins Publishing.

Talbot, M. (2007). Media Discourse: Represnetation and Interaction. Edinburgh: Edinburgh University Press.

(2010). Language and Gender. USA: Polity Press.

Thompson, John B. (1984). Studies in the Theory of Ideology. Los Angeles: University of California Press.

van Dijk, T. (1996). Discourse, Power and Access. In Carmen Rosa and Malcolm Coulthard (Eds.), Texts and Practices. (pp. 84-103). London: Roultedge.

(1997a). The Study of Discourse. In Teun van Dijk. (Ed.), Discourse Studies: A Multidisciplinary Introduction. Volume 1. (pp. 1-34). London: Sage Publication.

(1997b) Discourse as Interaction in Society. In (Teun A. van Dijk Ed.), Discourse as Social Interation. Discourse Studies: A Multidisciplinary Introduction. Volume 2. London: Sage Publications.

(1998). Ideology: A Multidisciplinary Approach. London: Sage Publications.

(2002) Multidisciplinary CDA: a Plea for Diversity. In Ruth Wodak (Ed.) Methods of Critical Discourse Analysis. (pp. 95-119). London: Sage Publications.

(2006a). Politics, Ideology, and Discourse. In K. Brown (Ed.) Encyclopedia of Language and Linguistics. (pp. 725-740). Amsterdam: Elsevier publishing.

(2006b).Discourse, Context and Cognition. Discourse Society, 8(1), 159-177.

(n.d.) Ideological Discourse Analysis [PDF document]. Retrieved from Lecture Notes Online Web site:http://www.discourses.org/OldArticles/_Ideological_discourse_analysis.pdf

van Leeuwen, T. (1996). The Representation of Social Actor. In Carmen Rosa Coulthard and Malcolm Coulthard (Eds.), Texts and Practices. (pp. 32-70). London: Roultedge.

(2008). Discourse and Practice: New Tools for Critical Discourse Analysis. Oxford: Oxford University Press.

(2009) Critical Discourse Analysis. In Jan Renkema (Ed.). Discourse, of Course: An Overview of Research in Discourse Studies. (pp. 277-292). USA: John Benjamins Publishing.

Wang, J. (2006). Questions and the Exercise of Power, Discourse \& Society, 17 (4), 529-548.

Wodak, R. (1997). Introduction: Some Important Issues in the Research of Gender and Disocurse. In Ruth Wodak (ED.)

Gender and Discourse. (pp.4-20).UK: sage publications.

(2002). What CDA is about: A Summary of its History,Important Concepts and its Developments. In Ruth Wodak and Michael Meyer (Eds.) Methods of Critical Discourse Analysis. (pp. 1-12). London: Sage Publications. 
Wodak, Rh. and Ludwig, C. (1999a). Introduction. In Ruth Wodak and Christoph Ludwig (Eds.) Callenges in a Changing World: Issues in Critical Discourse Analysis. (pp. 11-20). Amsterdam: Die Deutsche Bibliothek.

. (Eds). (1999b). Callenges in a Changing World: Issues in Critical Discourse Analysis. Amsterdam: Die Deutsche Bibliothek.

Wodak, R and Meyer, M (eds). (2002). Methods of Critical Discourse Analysis. London: Sage Publications.

Wodak, R. \& Clarke, I. (2009). Organizational Decision-making, Discourse, and Power: Integrating Across Contexts and Scales. Discourse \& Communication, 3 (3), 273-302. 